\title{
Correlation Between the Length and Weight of Arius maculatus off the Southwestern Coast of Taiwan
}

\author{
Wu-Shan Chu ${ }^{1,2^{*}}$, Yi-You Hou ${ }^{3}$, Yih-Tsong Ueng ${ }^{4}$ and Jiang-Ping Wang ${ }^{1,2}$ \\ ${ }^{1}$ Department of Life Sciences; National Cheng Kung University; Tainan 701; Taiwan. ${ }^{2}$ Marine Biology and \\ Cetacean Research Center; National Cheng Kung University; Tainan 701, Taiwan. ${ }^{3}$ Department of Electrical \\ Engineering; Far East University; Tainan 744; Taiwan. ${ }^{4}$ Department of Environmental Engineering; Kun Shan \\ University; Tainan 710; Taiwan
}

\begin{abstract}
In this study, Arius maculatus were collected using the samples caught by bottom trawling off the southwestern coast of Taiwan. Length-weight and length-length, fork (FL), standard (SL) and total (TL) lengths, relationships were determined. The relationships between the lengths were all significantly linear $(p<0.01)$, the $b$ value in the length-weight relationship for this value was significantly lower than 3 in the fall $(p<0.01)$, when the temporal changes were taken into account, indicating that only the sampling time affected the growth pattern of A. maculatus. The growth was isometric in the spring, summer and winter, but it was negative and allometric in the fall.
\end{abstract}

Key words: Arius maculatus, Length-Weight Relationship, Growth, Stand Length (SL)

\section{INTRODUCTION}

Fish length is an important point in the studies of fish growth, such as total lengths (TL), fork (FL) lengths and standard length (SL). When making comparisons between the populations, it is essential to use the standard measures for all the populations so that the results would be more reliable (Murat et al. 2004). Thus, this is utilized for the length-length relationship of the species under various environmental conditions (Murat et al. 2004). The length-weight relationships of fish are basic biological data that can be used in the studies of their population, and thus for the management of the species and their fisheries (Le Cren 1951; Shafi and Quddus 1974), as well as to provide a measurement of biomass (Petrakis and Stergiou 1995; Dulčić and Kraljević 1996; Froese, 1998), the length-weight relationships are also useful for comparing the life history and morphological aspects of the populations inhabiting different regions (Gonçalves et al. 1997; Stergiou and Moutopoulos 2001).

The early studies on Arius maculatus were mainly on the growth and food habitat (Mazlan et al., 2008). However, the estimation of the lengthweight relationship was common in these studies; they presented no evidence about the length-length relationship. The purpose of this study was to build life history parameters of A. maculatus, and specifically the length-weight relationship.

\section{MATERIALS AND METHODS}

The specimens of A.maculatus were collected on a monthly basis from February 2009 to March 2010. These fishes were caught by bottom trawling off the coast of southwestern Taiwan. Among these

*Author for correspondence: bowin1109@gmail.com 
catches, about 30 specimens were selected randomly to measure the fork length (FL) to nearest $0.1 \mathrm{~cm}$ and bodyweight $(\mathrm{BW})$ to nearest $0.1 \mathrm{~g}$.

The length-weight relationship is described by the following exponential regression equation: $W=$ $a L^{b}$, where $W$ is the body weight $(\mathrm{kg}), L$ is the fork length $(\mathrm{cm})$, the parameters $a$ and $b$ are calculated by the least-squares regression for the males and females seasonally (spring, summer, fall and winter). The weight-length relationships curves were compared with all the four seasons, and the variation in $b$ values from $\mathrm{t} 3$ were tested by the $t$ test for evaluating the growth curve. When the $b$ value in length-weight relationship was equal to or did not show statistically significant deviation from 3, the growth was isometric, whereas the positive or negative allometric growth occurred when the $b$ value deviated significantly from 3 (Ricker 1975; Erkoyuncu 1995).

\section{RESULTS}

The results of the relationships among the total, fork and standard lengths were determined by using the length measures of 452 A. maculatus specimens (Table 1).

Table 1 - Length-length relationships of Arius maculates.

\begin{tabular}{cccccc}
\hline Lengths & $\mathbf{n}$ & $\mathbf{a}$ & $\mathbf{b} \pm$ SE & $\mathbf{r}^{2}$ & Confidence Limits (95\%) \\
\hline TL-FL & 452 & -0.2548 & $1.1843 \pm 0.0050$ & 0.99 & $1.1745 \sim 1.2823$ \\
TL-SL & 452 & 0.1517 & $1.0550 \pm 0.0047$ & 0.99 & $1.0458 \sim 1.0642$ \\
FL-SL & 452 & -0.0928 & $1.2509 \pm 0.0072$ & 0.99 & $1.2368 \sim 1.2650$
\end{tabular}

$\mathrm{TL}=$ total length; $\mathrm{FL}=$ fork length; $\mathrm{SL}=$ standard length; $\mathrm{n}=$ number; $\mathrm{a}, \mathrm{b}=$ regression coefficients; $\mathrm{r}^{2}=$ correlation coefficient; Confidence Limits $(95 \%)=$ range of $\mathrm{b}$.

All the relationships were significantly linear $(\mathrm{p}<0.01, \mathrm{r}>0.99)$. The length-weight relationship determined for the seasons, and $b$ values varied between 2.83 and 3.04. These values calculated for the spring, summer, fall and winter as $2.93,3.04$, 2.83 and 2.91 , respectively. The variations in $b$ values from 3 were not statistically significant and indicated an isometric growth for the overall population when the seasons effects were not taken into account (Table 2 and Fig. 1(a)-(e)). The variations in $b$ values from 3 were not statistically significant in the spring, summer, winter or, but were in the fall $(\mathrm{p}<0.01)$, implying that while the growth of A. maculatus was negatively allometric during the fall, it was isometric during the rest of the year.

Table 2 - Length-weight relationship parameters of Arius maculates according to the seasons

\begin{tabular}{cccccccc}
\hline Factors & $\mathbf{N}$ & $\mathbf{a}$ & $\mathbf{b} \pm \mathbf{S E}$ & $\mathbf{r}^{2}$ & $\begin{array}{c}\text { Confidence Limits } \\
\mathbf{( 9 5 \% )}\end{array}$ & $\begin{array}{c}\mathbf{t} \text { value (difference } \\
\text { of b from 3) }\end{array}$ & $\mathbf{p}$ \\
\hline Winter & 1185 & 0.017 & $2.91 \pm 0.019$ & 0.95 & $2.873 \sim 2.947$ & -4.73 & $<0.001$ \\
Spring & 407 & 0.017 & $2.93 \pm 0.043$ & 0.92 & $2.846 \sim 3.014$ & -1.63 & 0.104 \\
Summer & 407 & 0.013 & $3.04 \pm 0.025$ & 0.97 & $2.991 \sim 3.089$ & 1.6 & 0.11 \\
Fall & 125 & 0.017 & $2.83 \pm 0.085$ & 0.90 & $2.662 \sim 2.998$ & -2 & 0.048 \\
Overall & 2124 & 0.015 & $2.95 \pm 0.013$ & 0.96 & $2.925 \sim 2.975$ & -3.84 & $<0.01$ \\
\hline
\end{tabular}

$\mathrm{N}=$ number; $\mathrm{a}, \mathrm{b}=$ regression coefficients; $\mathrm{r}^{2}=$ correlation coefficient; Confidence Limits $(95 \%)=$ range of $\mathrm{b}$; $\mathrm{p}=$ significant. 


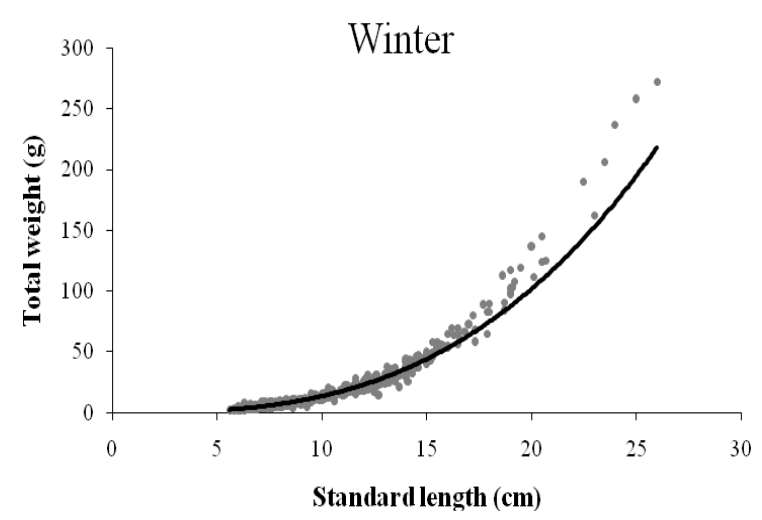

Figure 1 (a)

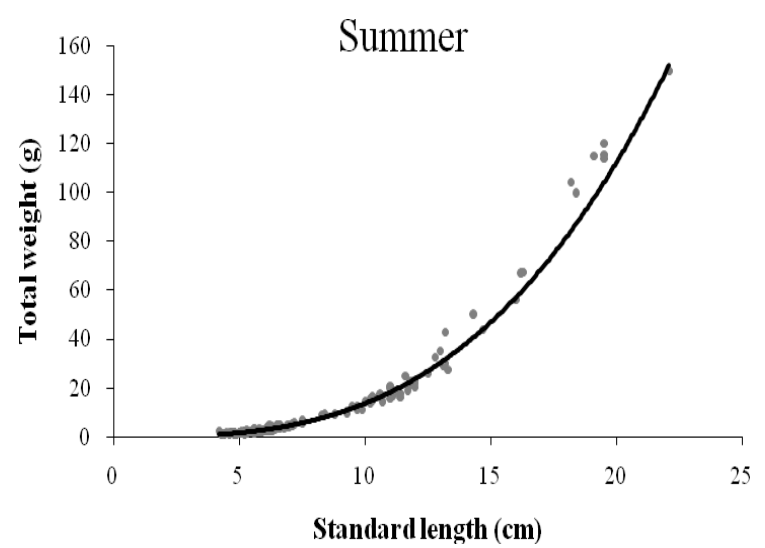

Figure 1 (c)

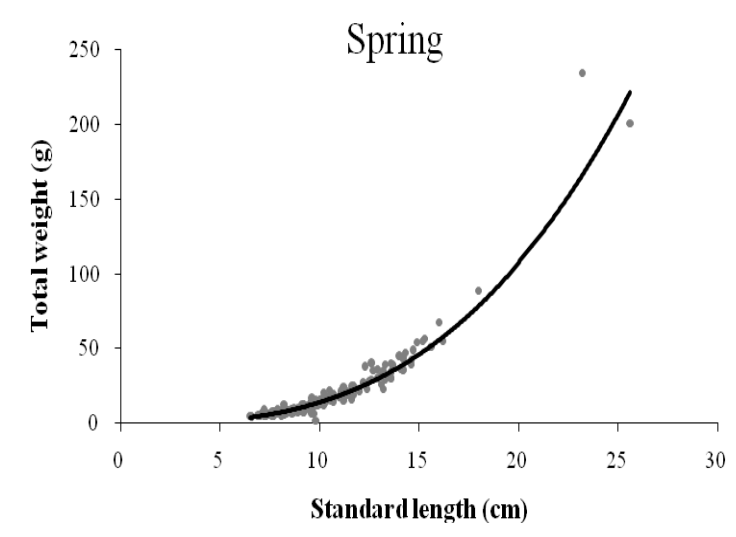

Figure 1 (b)

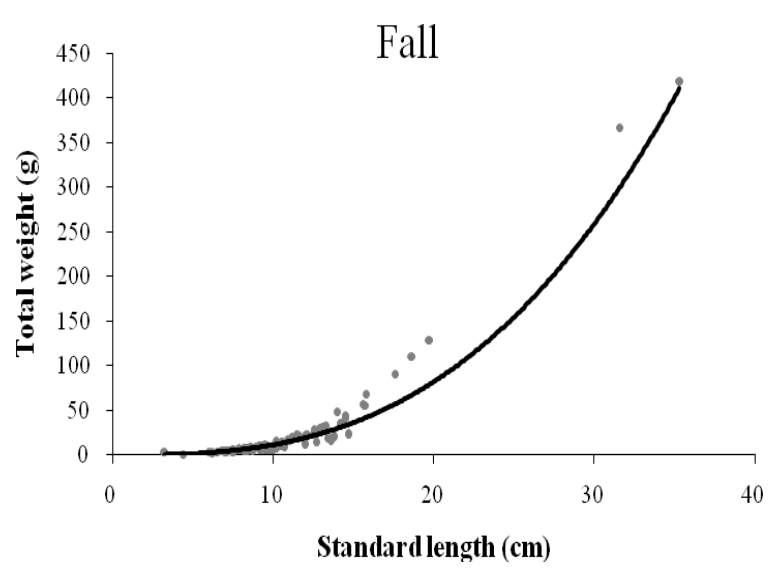

Figure 1 (d)

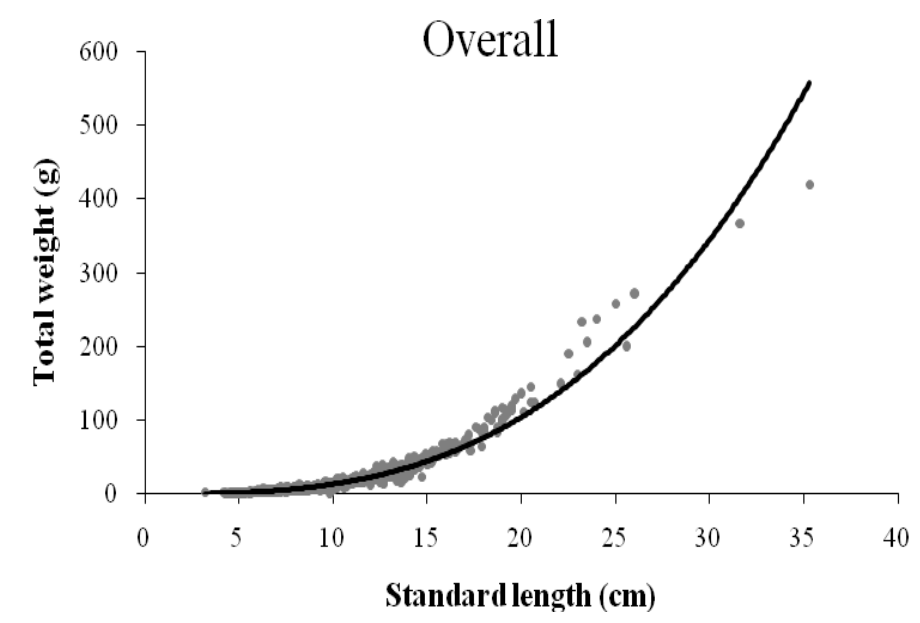

Figure 1 (e)

\section{DISCUSSION}

A. maculatus is an economically important species in Malaysia. There are few studies on the basic biology of this species (Mazlan et al. 2008).
In this study, the length-weight (according to sampling time) and length-length (overall) relationships of $A$. maculates was estimated off the southwestern coast of Taiwan. The length-length relationships were significantly linear. 
Moutopoulos and Stergiou (2002) also found significantly linear relationships among TL, FL and SL in some fish species in the Aegean Sea. These significantly linear relationships among the length parameters showed that certain fish species exhibited characteristic morphological features (Murat et al. 2004).

The $b$ value was used in the length-weight relationship as the indicator of the growth type of A.maculatus to find out whether there deviation from isometric growth had occurred at the sampling times. When the seasonal variations were considered, the $b$ value reached its maximum value of $3.04(\mathrm{r}=0.97, \mathrm{~N}=407)$ during the summer (June, July and August) and its minimum value of $2.83(\mathrm{r}=0.90, \mathrm{~N}=125)$ during the fall (September, October and November). The $b$ value recorded in the fall was significantly lower than $3(\mathrm{p}<0.01) \mathrm{m}$ indicating a negative allometric growth during this season. However, the $b$ value recorded in the overall was significantly lower than $3(p<0.01)$ indicating a negative allometric growth during this study period.

The $b$ value in the length-weight relationship of fish can be used as an indicator of food intake and growth pattern, and may differ according to such biotic and abiotic factors as water temperature, food availability and habitat type (Wootton 1992; Avsar 1998). Hence, the $b$ value recorded in the fall was insignificantly lower than 3 indicated a negative allometric growth during the season in this study. However, adequate feeding and gonad development increases fish weight and $b$ values (Nikolsky 1963; Arslan 2003). The result of this study, during the fall, when biological resources were insufficient and certain abiotic factors as water temperature were inadequate, Arius maculatus living off the southwestern coast of Taiwan could not feed sufficiently and demonstrated a negative allometric growth. In contrast, environmental conditions did not change the normal isometric growth of this species during the rest of the year.

\section{REFERENCES}

Arslan M. Coruh Havzası Anuri ve Cenker çylarında yaşayan alabalık, Salmo trutta Linneaus 1766, populasyonları uzerine araștırmalar [Ph.D Thesis]. Erzurum: Ataturk University; 2003.
Avsar D. Balıkçılık Biyolojisi ve Populasy on Dinamig. Adana, Turkey: Baki Kitabevi; 1988.

Dulčić J, Kraljević M. Weight-length relationships for 40 fish species in the eastern Adriatic (Croatian waters). Fish. Res. 1996; 28: 243-251.

Erkoyuncu, İ. Balıkçılık Biyolojisi ve Populasyon Dinami gi. Sinop: Ondokuz Mayıs Üniversitesi, Sinop Su ürünleri Fakültesi; 1995. P. 265.

Froese R. Length-weight relationships for 18 lessstudied fish species. J Appl Ichthyol. 1998; 14: 117118.

Gonçalves JMS, Bentes L, Lino PG, Ribeiro J, Canario AVM, Erzini K. Weight-length relationships for selected fish species of the small-scale demersal fisheries of the south and south-west coast of Portugal. Fish Res. 1997; 30: 253-256.

Le Cren ED. The length-weight relationship and seasonal cycle in gonadal weight and condition in the perch, Perca fluviatilus. J Anim Eco. 1951; 20: 201219.

Mazlan AG, Abdullah S, Shariman MG, Arshad A. On the biology and bioacoustic characteristic of spotted catfish Arius maculatus (Thunberg 1792) from the Malaysian Estuary. Res J Fish Hydro. 2008; 3: 63-70.

Moutopoulos DK. Stergiou KI. Length-weight and length-length relationships of fish species from the Aegean Sea (Greece). J Appl Ichthyol. 2002; 18: 200203.

Murat A, Ayhan Y, Serdar B. Length-weight relationship of brown trout, Salmo trutta L., Inhabiting Kan Stream, Coruh Basin, North-Eastern Turkey. Turk J Fish Aqua Sci. 2004; 4: 45-48.

Nikolsky GW. The ecology of fishes. London and New York: Academic Press; 1963. p. 352

Petrakis G, Stergiou KI. Weight length relationships for 33 fish species in Greek waters. Fish Res. 1995; 21: 465-469.

Ricker WE. Computation and interpretation of biological statistics of fish populastions. Bull Fish Resh Board Can. 1975; 191: 203-233.

Shafi M, Quddus MMA. The length-weight relationship and condition factor in Hilsa ilisha (Hamilton) (Clupeiformes: Clupeidae). Bangladesh J Zool. 1974; 2(2): 179-185.

Stergiou KI, Moutopoulos DK. A review of lengthweight relationships of fishes from Greek marine waters. Naga: the ICLARM quarterly. 2001; 24(1-2): 23-39.

Wootton RS. Fish Ecology. Printed in Great Britain by Thomson Litho Ltd, Scotland; 1992. 